\title{
Effects of flunixin meglumine on pyrexia and bioenergetic variables in postparturient dairy cows ${ }^{1}$
}

\author{
G. Shwartz, ${ }^{*}$ K. L. Hill, † M. J. VanBaale, ${ }^{* 2}$ and L. H. Baumgard ${ }^{* 3}$ \\ *Department of Animal Sciences, The University of Arizona, Tucson 85721 \\ †Schering Plough Animal Health, Kenilworth, NJ 07033
}

\begin{abstract}
Study objectives were to determine whether a nonsteroidal antiinflammatory drug would reduce parturition-induced inflammation and fever and consequently improve appetite, bioenergetic parameters, and production variables in transitioning dairy cows. Multiparous cows $(\mathrm{n}=26)$ were randomly assigned to 1 of 2 treatments beginning at parturition: 1) flunixin meglumine (FM; $2.2 \mathrm{mg} / \mathrm{kg}$ of BW; Banamine, $50 \mathrm{mg} /$ $\mathrm{mL}$, Schering-Plough Animal Health, Kenilworth, NJ), or 2) saline (control) at $2.0 \mathrm{~mL} / 45.5 \mathrm{~kg}$ of BW. All treatments were administrated i.v. daily for the first 3 $\mathrm{d}$ in milk (DIM). Individual milk yield and dry matter intake (DMI) were recorded daily for the first 35 DIM. Rectal temperature was measured daily at 0700 and $1600 \mathrm{~h}$ for the first 7 DIM. Milk composition was determined on 2, 7, 14,21, 28, and 35 DIM and blood plasma was collected on 1, 2, 3, 4, 7, 14, 21, 28, and 35 DIM. Body weight and body condition score were determined on $-7,1,7,14,21,28$, and 35 DIM. Flunixin meglumine treatment slightly increased rectal temperature $\left(38.99\right.$ vs. $\left.38.76^{\circ} \mathrm{C}\right)$ during the first 7 DIM and reduced overall DMI (22.04 vs. $19.48 \mathrm{~kg} / \mathrm{d})$, but there were no treatment differences in overall milk yield $(35.2 \mathrm{~kg} / \mathrm{d})$, $3.5 \%$ fat-corrected milk $(37.6 \mathrm{~kg} / \mathrm{d})$, energy-corrected milk $(37.7 \mathrm{~kg} / \mathrm{d})$, DMI $(2.97 \%$ of BW), or overall energy balance $(-2.32 \mathrm{Mcal} / \mathrm{d})$. There were no treatment differences in milk fat $(3.91 \%)$, protein $(3.32 \%)$, or lactose $(4.57 \%)$. Treatment had no effect on plasma glucose $(66.5 \mathrm{mg} / \mathrm{dL})$ or nonesterified fatty acids (553 $\mu \mathrm{Eq} / \mathrm{L})$, but plasma urea nitrogen tended to be less in FM-treated cows (16.4 vs. $14.5 \mathrm{mg} / \mathrm{dL})$. Daily FM administration to cows for the first $3 \mathrm{~d}$ after parturition slightly increased rectal temperatures by $0.23^{\circ} \mathrm{C}$,

\footnotetext{
Received July 25, 2008.

Accepted January 12, 2009.

${ }^{1}$ This work was partially funded by Schering Plough Animal Health

${ }^{2}$ Current address: Natural Milk Dairy Company, Kirkman, IA

${ }^{3}$ Corresponding author: baumgard@ag.arizona.edu
} (Kenilworth, NJ) and The University of Arizona Experiment Station (Tucson, AZ), no. ARZT-136339-H-24-130. 51447.
\end{abstract}

reduced feed intake, and did not improve production or energetic variables during the first 35 DIM in transition dairy cows.

Key words: flunixin meglumine, transition cow, pyrexia, metabolism

\section{INTRODUCTION}

During the periparturient period $(\sim 3$ wk prepartum to $\sim 3$ wk postpartum), dairy cows experience biological and logistical challenges that may impair their ability to maximize future performance. One of the primary issues is energy balance (EBAL), which is the difference between the energy consumed and the energy used for maintenance and production. During early lactation, cows typically cannot consume enough calories to meet their requirements for maintenance and copious milk yield and they enter into a state of negative EBAL, which is associated with metabolic disorders, reproductive failure, and probably reduced milk synthesis (Drackley, 1999; Odens et al., 2007).

Inflammation is the specific or nonspecific immune response to tissue injury or to foreign (or perceived as foreign) organisms (Tizard, 1996). After parturition, the uterus quickly experiences a variety of structural and immunological events, including fetal membrane release, ischemic necrosis and sloughing of the caruncular epithelium, healing of damaged tissue and growth of new epithelium, and shortening of the muscle fibers of the myometrium (allowing it to return to its prepartum size; Bondurant, 1999). In addition to uterine recovery, the postpartum period is often associated with a uterine bacterial contamination (Bondurant, 1999). In some herds, as high as $40 \%$ of postpartum cows are treated for uterine infection (Lewis, 1997), which may delay involution and reduce ovarian activity and fertility (Hussain and Daniel, 1991; Amiridis et al., 2001). Uterine infections can and do frequently occur after calving and before formation of the first corpus luteum (Sheldon et al., 2006), and clinical signs include fever, anorexia, depression, reduced milk production, abdominal pain, and uterine discharge (Sheldon et al., 2004). 
Nonsteroidal antiinflammatory drugs have antipyretic and antiinflammatory properties and are commonly and safely used in food production animals (Abramson, 1991). Nonsteroidal antiinflammatory drugs inhibit cyclooxygenase activity and block prostaglandin synthesis, which is known (in large part) to mediate inflammation symptoms, including fever, hyperalgesia, increased vascular permeability, and edema (Morteau, 2000). Flunixin meglumine (FM) is a nonsteroidal antiinflammatory drug that has recently (2004) been approved by the FDA for use in lactating dairy cows for controlling pyrexia associated with bovine respiratory disease and endotoxemia, and for reducing inflammation during endotoxemia. We hypothesized that FM treatment for the first 3 DIM would reduce parturition-induced inflammation and fever, which could result in improved appetite, and consequently could enhance production and improve bioenergetic variables in transition dairy cows.

\section{MATERIALS AND METHODS}

\section{Design, Animals, and Treatments}

The University of Arizona Institutional Animal Care and Use Committee approved all procedures involving animals. Multiparous cows $(\mathrm{n}=26)$ were housed together in a single pen at The University of Arizona dairy. Approximately 32 d before parturition, cows were assigned randomly to 1 of 2 treatments: 1) FM at $2.2 \mathrm{mg} / \mathrm{kg}$ of BW $(\mathrm{n}=14$; Banamine, $50 \mathrm{mg} / \mathrm{mL}$, Schering-Plough Animal Health, Kenilworth, NJ) or 2) saline at $2.0 \mathrm{~mL} / 45.5 \mathrm{~kg}$ of $\mathrm{BW}$ (control, $\mathrm{n}=12$ ). The groups had similar 305-d mature equivalent milk yields (305ME; 11,865 and 11,795 $\mathrm{kg}$, respectively), parities (2.07 and 2.25, respectively), and calving dates (248 d pregnant). Treatments were administrated i.v. via a jugular catheter within the first $5 \mathrm{~h}$ postpartum and daily for the first 3 DIM with a $2.16 \times 51 \mathrm{~mm}$ (diameter $\times$ length) Midicut Intravenous Cannula (MWI Veterinary Supply Co., Glendale, AZ) to insert and guide flexible Tygon Microbore Tubing (i.d. $=1.02$ mm, o.d. $=1.78 \mathrm{~mm}$; VWR Intl., Brisbane, CA). The use of FM to reduce parturition-induced inflammation and fever is not approved by the FDA for lactating dairy cows and was used in this study as extra-label.

Cows were trained to eat from Calan gates (Calan Broadbent feeding system, American Calan, Northwood, $\mathrm{NH}$ ), and individual feed intake was recorded daily from approximately $14 \mathrm{~d}$ before expected parturition to 35 DIM. Twice daily, cows were fed ad libitum portions of fresh feed at 0700 and $1700 \mathrm{~h}$, and feed weighbacks were measured and recorded daily at 0700 h. Cows were fed a close-up TMR formulated (Dairy
Table 1. Ingredients and chemical composition of $\operatorname{diets}^{1}$

\begin{tabular}{lcc}
\hline Composition & Prepartum $^{2}$ & Postpartum $^{3}$ \\
\hline Ingredient, \% of DM & & \\
Alfalfa hay & 68.08 & 65.88 \\
Whole cottonseed & 3.25 & 8.76 \\
Barley & 12.64 & 9.84 \\
Steam-flaked corn & 12.64 & 11.33 \\
Supplement & 3.39 & 2.5 \\
Maxxer & - & 1.68 \\
Chemical analysis, \% of DM & & \\
CP & 21.45 & 19.02 \\
NDF & 29.58 & 27.02 \\
ADF & 23.57 & 20.96 \\
NE & 1.63 & 1.76 \\
\hline
\end{tabular}

${ }^{1}$ Values represent an average of samples collected and composited throughout the trial. Dry matter averaged 50 and $52 \%$ for the prepartum and postpartum diets, respectively.

${ }^{2}$ The prepartum supplement contained $2.10 \%$ fat, $7.16 \%$ Ca, $0.14 \%$ $\mathrm{P}, 4.00 \% \mathrm{Mg}, 3.50 \% \mathrm{~S}, 0.17 \% \mathrm{~K}, 0.06 \% \mathrm{Na}, 34.67 \% \mathrm{Cl}, 1628.8 \mathrm{mg} /$ $\mathrm{kg}$ of Zn, $933.6 \mathrm{mg} / \mathrm{kg}$ of Mn, $403.3 \mathrm{mg} / \mathrm{kg}$ of Fe, $497.1 \mathrm{mg} / \mathrm{kg}$ of Cu, $54.0 \mathrm{mg} / \mathrm{kg}$ of Co, $11.0 \mathrm{mg} / \mathrm{kg} \mathrm{Se}, 0.9 \mathrm{mg} / \mathrm{kg}$ of Mo, $54.1 \mathrm{mg} / \mathrm{kg}$ of I, 537.5 of $\mathrm{IU} / \mathrm{g}$ of vitamin $\mathrm{A}, 65.9 \mathrm{IU} / \mathrm{g}$ of vitamin $\mathrm{D}$, and $7.1 \mathrm{IU} / \mathrm{g}$ of vitamin $\mathrm{E}$.

${ }^{3}$ The postpartum supplement contained $1.47 \%$ fat, $5.74 \%$ Ca, $6.47 \%$ $\mathrm{P}, 4.06 \% \mathrm{Mg}, 0.50 \% \mathrm{~S}, 0.23 \% \mathrm{~K}, 15.25 \% \mathrm{Na}, 2.33 \% \mathrm{Cl}, 1776.4 \mathrm{mg} / \mathrm{kg}$ of Zn, $1,832.6 \mathrm{mg} / \mathrm{kg}$ of $\mathrm{Mn}, 1,102.9 \mathrm{mg} / \mathrm{kg}$ of $\mathrm{Fe}, 330.5 \mathrm{mg} / \mathrm{kg}$ of $\mathrm{Cu}$, $77.7 \mathrm{mg} / \mathrm{kg}$ of Co, $15.7 \mathrm{mg} / \mathrm{kg} \mathrm{Se}, 7.0 \mathrm{mg} / \mathrm{kg}$ of Mo, $44.3 \mathrm{mg} / \mathrm{kg}$ of I, 309.2 of IU/g of vitamin A, $30.6 \mathrm{IU} / \mathrm{g}$ of vitamin $\mathrm{D}$, and $1.0 \mathrm{IU} / \mathrm{g}$ of vitamin $\mathrm{E}$.

${ }^{4}$ Calcium salts of palm oil (Tarome Inc., Eloy, AZ).

Nutrition Services, Chandler, AZ) to meet or exceed the predicted energy, protein, mineral, and vitamin requirements (NRC, 2001). Alfalfa hay was the main forage source, and steam-flaked corn was the primary concentrate (Table 1). Feed was sampled every other day and $\mathrm{DM}$ content was determined $\left(100^{\circ} \mathrm{C}\right.$ for a minimum of 7 d). The TMR was sampled weekly and analyzed by wet chemistry methods (Dairy One Inc., Ithaca, NY). After parturition, cows were fed a lactating TMR formulated to meet or exceed the predicted energy, protein, mineral, and vitamin requirements (NRC, 2001; Table 1). Shade and fresh water was available at all times.

Cows were milked at 0900 and $2100 \mathrm{~h}$ and yield was recorded daily. Milk from FM-treated cows was not sold for $36 \mathrm{~h}$ past the last treatment, per FDA guidelines. Milk samples were obtained from each cow on $2,7,14,21$, and 35 DIM and were stored at $-4^{\circ} \mathrm{C}$ (bronopol tablet, D\&F Control Systems, San Ramon, CA) until analyzed at the Arizona DHIA (Tempe, AZ). Blood samples were obtained from the coccygeal vessels from each cow on $-9 \pm 5,1,2,3,4,7,14,21,28$, and 35 DIM. Samples were kept on ice until centrifuged at $3,000 \times g$ for $15 \mathrm{~min}$. Plasma was split into 2 aliquots, immediately frozen at $-20^{\circ} \mathrm{C}$, and later analyzed for NEFA, plasma urea nitrogen (PUN), and glucose concentrations. Plasma NEFA, plasma glucose, and PUN concentrations were determined enzymatically by us- 
ing commercially available kits validated for use in our laboratory (lot 37E5, NEFA C kit, Wako Chemicals USA Inc., Richmond VA; lots 08976, 08436, 07785, and 6612, Urea Nitrogen Reagent, Anaheim, CA; lot EF971, Autokit Glucose, Wako Chemicals USA Inc.). These procedures were scaled down and conducted in 96-well microplates (Rainin Instrument LLC, Oakland, CA) and read using a microplate photometer (Multiskan Ascent, Thermo Electron Corporation, Vantaa, Finland). The interassay coefficients were $3.9,5.1$, and $2.5 \%$, and intraassay coefficients were $3.9,5.3$, and $2.6 \%$ for the NEFA, PUN, and glucose assays, respectively.

Body weights were recorded on $-9 \pm 5,1,7,14,21$, 28 , and 35 DIM before the morning milking. Body condition scores were estimated independently by 2 trained individuals on $-9 \pm 5,1,7,14,21,28$, and 35 DIM by using a 5-point system (Wildman et al., 1982). Body temperatures were measured with a rectal thermometer (M700 Digital Thermometer, GLA Agricultural Electronics, San Luis Obispo, CA) at 0700 and $1600 \mathrm{~h}$ on all cows for the first 7 DIM. Cows were observed daily for general health status.

\section{Calculations}

Postpartum EBAL was estimated by using the following equation (NRC, 2001): EBAL = net energy for intake - $\left(\mathrm{NE}_{\mathrm{M}}+\mathrm{NE}_{\mathrm{L}}\right)$. Net energy for lactation was estimated by the following equation: $[(0.0929 \times$ fat $\%)$ $+(0.0547 \times$ true protein \% $)+(0.0395 \times$ lactose $\%)]$ $\times$ milk production. Daily EBAL values were subjected to a third-order polynomial regression analysis to minimize variation, and predicted daily energy values from these equations were used in the statistical analysis as described previously (Odens et al., 2007). Third-order polynomial regression analysis was conducted using the scatter plot in Microsoft Office Excel 2003 (Microsoft Corporation, Redmond, WA). Days to EBAL nadir were identified as the day at which the lowest predicted net EBAL value occurred. The daily yields of $3.5 \% \mathrm{FCM}$ and ECM were calculated (NRC, 2001) by using the following equations: $3.5 \% \mathrm{FCM}=(0.432 \times$ milk yield $)$ $+(16.23 \times$ milk fat yield $) ; \mathrm{ECM}=(0.327 \times$ milk yield $)$ $+(12.95 \times$ milk fat yield $)+(7.2 \times$ milk protein yield $)$. Feed efficiency was calculated by using the following equation: feed efficiency $=3.5 \% \mathrm{FCM} / \mathrm{DMI}$.

\section{Statistical Analysis}

Analysis included d 7 prepartum, daily data from parturition to 7 DIM, and weekly data (collapsed 7-d means) from parturition until 35 DIM. Because of the variability in BW $(757 \pm 55$ and $722 \pm 97 \mathrm{~kg}$ for control and FM-treated cows, respectively) before calving and after randomly assigning treatment, milk yield and DMI were also analyzed as a percentage of BW. Milk yield, milk yield as a percentage of BW, DMI, DMI as a percentage of BW, EBAL, feed efficiency, and daily mean (a.m. and p.m.) rectal temperature were analyzed by repeated measures using PROC MIXED (SAS Institute, 2005) with an autoregressive covariance structure and day or week of lactation as the repeated affect. Plasma NEFA, plasma glucose, and PUN concentrations were an analyzed by repeated measures using PROC MIXED (SAS Institute, 2005) and incorporated the spatial power law for unequally spaced data and day as the repeated effect. The previous $305 \mathrm{ME}$ was used as a covariate on all measurements. Dry matter intake from the week before calving was also used as a covariate on production variables, but this did not alter data interpretation; therefore, the $305 \mathrm{ME}$ was used on all measured variables. The model contained the day or week of lactation, treatment, and day or week of lactation $\times$ treatment interactions. Cows were the random effect, and day or week of lactation, treatment, and the DIM or week of lactation $\times$ treatment interaction were the fixed effects. Milk components were analyzed by repeated measures using PROC MIXED (SAS Institute, 2005), with an autoregressive covariance structure and day of lactation as the repeated affect. The model contained day of lactation, treatment, and day $\times$ treatment interactions. Cows were the random effect, and the day of lactation, treatment, and day of lactation $\times$ treatment interaction were the fixed effects. The EBAL nadir was analyzed using PROC MIXED (SAS Institute, 2005), with treatment as the dependent variable, and did not contain a time or repeated component. Cows with a rectal temperature greater than $39.5^{\circ} \mathrm{C}$ were classified as febrile, and the binary response was analyzed using PROC NLMIXED (SAS Institute, 2005).

\section{RESULTS}

There were obvious time effects on most production and metabolic variables, as would be expected during the transition period (Tables 2, 3, and 4). During the first 7 DIM, FM-treated cows had a slightly greater (38.99 vs. $38.76^{\circ} \mathrm{C} ; P=0.03$; Table 2 and Figure 1 ) daily rectal temperature. There was an interaction between treatment and time; both groups had similar rectal temperatures at the beginning and end of the first week of lactation, but FM-treated cows had greater $(P$ $=0.03$; Figure 1) rectal temperatures at 3 and 4 DIM. Flunixin meglumine-treated cows tended $(P=0.08)$ to experience a fever (rectal temperature greater than $39.5^{\circ} \mathrm{C}$ ) more often than control cows (4 vs. 9 cows) during the first 7 DIM (data not shown). 
Table 2. Effects of flunixin meglumine (FM) treatment in the first 3 DIM on production variables of dairy cows in the first 7 DIM

\begin{tabular}{|c|c|c|c|c|c|c|}
\hline \multirow[b]{2}{*}{ Variable } & \multicolumn{2}{|c|}{ Treatment $^{1}$} & \multirow[b]{2}{*}{ SEM } & \multicolumn{3}{|c|}{$P$-value } \\
\hline & Control & FM & & $\mathrm{TRT}^{2}$ & DIM & $\mathrm{TRT} \times \mathrm{DIM}$ \\
\hline $\mathrm{RT},{ }^{3} \mathrm{C}$ & 38.76 & 38.99 & 0.08 & 0.03 & 0.11 & 0.07 \\
\hline DMI, $\mathrm{kg} / \mathrm{d}$ & 18.83 & 14.80 & 0.60 & $<0.01$ & 0.28 & $<0.01$ \\
\hline DMI, as PBW ${ }^{4}$ & 2.52 & 2.10 & 0.10 & $<0.01$ & 0.08 & $<0.01$ \\
\hline Milk yield, $\mathrm{kg} / \mathrm{d}$ & 29.04 & 25.54 & 1.18 & 0.04 & $<0.01$ & 0.46 \\
\hline Milk yield, as PBW & 3.86 & 3.59 & 0.16 & 0.24 & $<0.01$ & 0.71 \\
\hline Feed efficiency & 1.7 & 2.2 & 0.2 & 0.08 & $<0.01$ & 0.29 \\
\hline $\mathrm{EBAL},{ }^{5} \mathrm{Mcal} / \mathrm{d}$ & -2.1 & -5.3 & 1.3 & 0.09 & $<0.01$ & 0.92 \\
\hline
\end{tabular}

${ }^{1}$ Treatments were $2.0 \mathrm{~mL}$ of saline $/ 45.5 \mathrm{~kg}$ of BW (control) or $2.2 \mathrm{mg}$ of $\mathrm{FM} / \mathrm{kg}$ of BW for the first 3 DIM.

${ }^{2}$ Treatment.

${ }^{3}$ Rectal temperature.

${ }^{4}$ Percentage of BW.

${ }^{5}$ Energy balance.

Dry matter intake was coincidentally less $(14.90$ vs. $13.26 \pm 0.50 \mathrm{~kg} / \mathrm{d} ; P=0.03$; data not shown) in cows destined for FM treatment during the week before calving. For the first 7 DIM, control cows had greater (18.83 vs. $14.80 \mathrm{~kg} / \mathrm{d} ; P<0.01$; Table 2) DMI and DMI as a percentage of BW (2.52 vs. $2.10 \% ; P<$ 0.01; Table 2). Additionally, there was an interaction between treatment and time for DMI and DMI as a percentage of BW during the first 7 DIM because there were no differences on the first day of lactation, but FM-treated cows had decreased DMI during the following $6 \mathrm{~d}$. Overall ( 1 to $5 \mathrm{wk}$ of lactation) DMI was less (22.04 vs. $19.48 \mathrm{~kg} / \mathrm{d} ; P<0.01$; Table 3$)$ in FM-treated cows for the duration of the study, but there was no overall effect $(2.98 \%$; Table 3$)$ on DMI when evaluated as a percentage of BW.
Milk yield was reduced $(29.04$ vs. $25.54 \mathrm{~kg} / \mathrm{d} ; P=$ 0.04; Table 2) in FM-treated cows during the first 7 DIM, but treatment had no effect (3.73\%; Table 2) on milk yield as a percentage of BW during this time. Treatment did not affect overall milk yield (35.18 $\mathrm{kg} / \mathrm{d}$ ), milk yield a percentage of BW (5.02\%), 3.5\% FCM $(37.64 \mathrm{~kg} / \mathrm{d})$, or ECM $(37.67 \mathrm{~kg} / \mathrm{d})$ during the first $5 \mathrm{wk}$ of lactation (Table 3). Milk fat (3.91\%), protein $(3.32 \%)$, and lactose $(4.57 \%$; Table 4$)$ were similar among treatments throughout the study.

Body weight $(705 \mathrm{~kg})$ and BCS (3.45; Table 3) were not affected by treatment throughout the study. Calculated EBAL tended to be greater $(-2.1$ vs. $-5.3 \mathrm{Mcal} / \mathrm{d}$; $P=0.09$; Table 2) in control cows during the first 7 DIM, but was similar $(-2.4 \mathrm{Mcal} / \mathrm{d}$; Table 3$)$ to that of FM-treated cows during the first 5 wk of lactation. The

Table 3. Effects of flunixin meglumine (FM) treatment in the first 3 DIM on production variables of dairy cows in the first 5 wk of lactation

\begin{tabular}{|c|c|c|c|c|c|c|}
\hline \multirow[b]{2}{*}{ Variable } & \multicolumn{2}{|c|}{ Treatment $^{1}$} & \multirow[b]{2}{*}{ SEM } & \multicolumn{3}{|c|}{$P$-value ${ }^{2}$} \\
\hline & Control & FM & & TRT & WOL & $\mathrm{TRT} \times \mathrm{WOL}$ \\
\hline DMI, kg/d & 22.04 & 19.48 & 0.49 & $<0.01$ & $<0.01$ & 0.35 \\
\hline DMI, as $\mathrm{PBW}^{3}$ & 3.07 & 2.89 & 0.10 & 0.24 & $<0.01$ & 0.35 \\
\hline Milk yield, kg/d & 36.13 & 34.23 & 1.34 & 0.33 & $<0.01$ & 0.30 \\
\hline Milk yield, as PBW & 4.99 & 5.04 & 0.17 & 0.83 & $<0.01$ & 0.14 \\
\hline $3.5 \%$ FCM yield, $\mathrm{kg} / \mathrm{d}$ & 38.33 & 36.95 & 1.64 & 0.56 & $<0.01$ & 0.54 \\
\hline ECM yield, $\mathrm{kg} / \mathrm{d}$ & 38.44 & 36.90 & 1.55 & 0.49 & $<0.01$ & 0.59 \\
\hline Feed efficiency & 1.8 & 2.0 & 0.1 & 0.15 & 0.12 & 0.54 \\
\hline $\mathrm{BW}, \mathrm{kg} / \mathrm{d}$ & 724 & 686 & 21 & 0.20 & $<0.01$ & 0.44 \\
\hline BCS & 3.56 & 3.34 & 0.10 & 0.15 & 0.55 & 0.75 \\
\hline $\mathrm{EBAL},{ }^{4} \mathrm{Mcal} / \mathrm{d}$ & -1.2 & -3.6 & 1.1 & 0.15 & $<0.01$ & 0.84 \\
\hline EBAL nadir, Mcal/d & -5.0 & -7.8 & 1.3 & 0.13 & & \\
\hline EBAL nadir, d & 14.0 & 11.5 & 1.6 & 0.29 & & \\
\hline
\end{tabular}

${ }^{1}$ Treatments were $2.0 \mathrm{~mL}$ of saline/45.5 kg of BW (control) or $2.2 \mathrm{mg}$ of $\mathrm{FM} / \mathrm{kg}$ of BW for the first 3 DIM.

${ }^{2} \mathrm{TRT}=$ treatment; WOL $=$ week of lactation.

${ }^{3}$ Percentage of BW.

${ }^{4}$ Energy balance. 


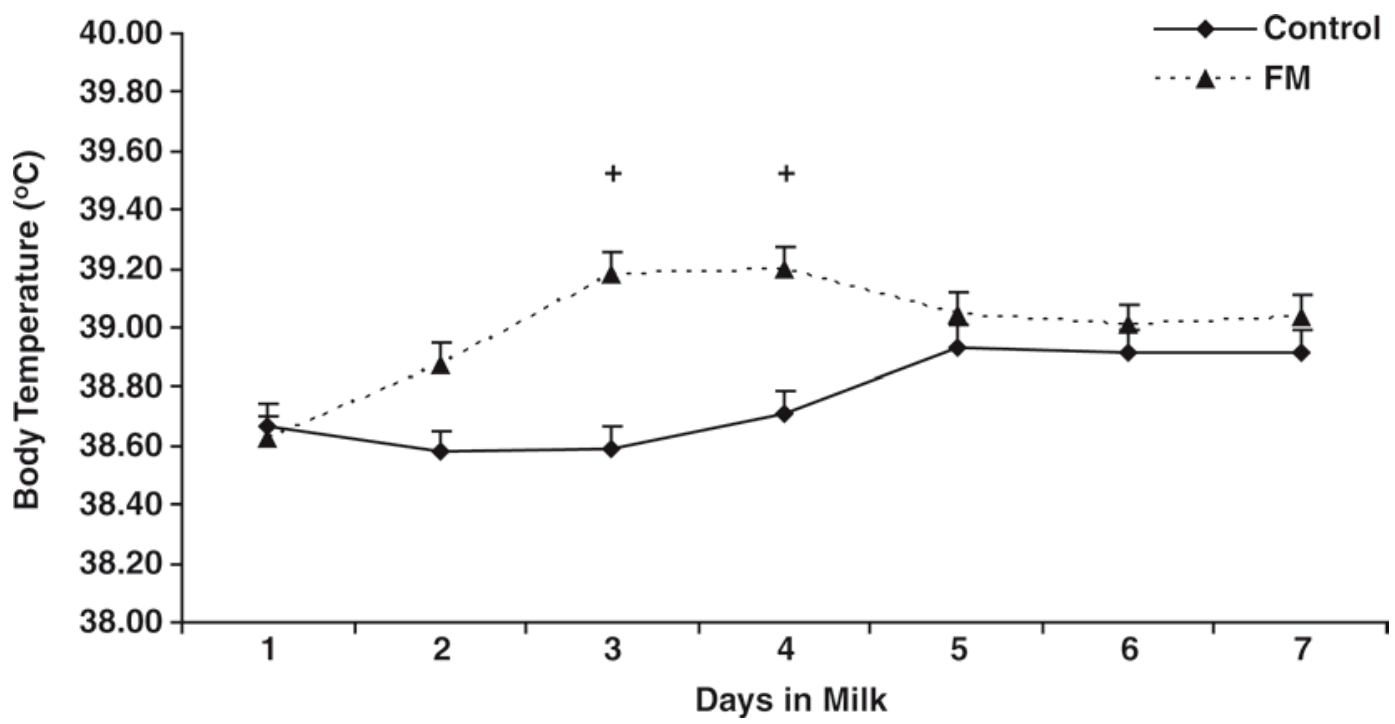

Figure 1. Effects of flunixin meglumine $(\mathrm{FM})$ on rectal temperature. Treatments were $2.0 \mathrm{~mL}$ of saline/45.5 kg of BW (control) or $2.2 \mathrm{mg}$ of FM $/ \mathrm{kg}$ of BW for the first 3 DIM. Values represent least squares means $(\mathrm{n}=12$ or 14$)$ for the control and FM, respectively. A plus sign ( + ) indicates a treatment $\times$ time interaction, with $0.05<P<0.1$.

EBAL nadir (-6.4 Mcal/d) and days to EBAL nadir $(12.8 \mathrm{~d}$; Table 2$)$ were unaffected by treatment. Feed efficiency tended to be increased ( 2.2 vs. $1.7 ; P=0.08$; Table 2) for FM-treated cows for the first 7 DIM, but was similar (1.9; Table 3) among treatments during the first 5 wk of lactation. Treatment had no overall effect $(P>0.05)$ on plasma glucose $(66.5 \mathrm{mg} / \mathrm{mL})$ or NEFA $(553 \mu \mathrm{Eq} / \mathrm{L}$; Figures $2 \mathrm{~A}$ and $2 \mathrm{~B})$ throughout the study, but PUN tended $(P=0.08)$ to be less (16.4 vs. 14.5 $\mathrm{mg} / \mathrm{dL}$; Figure 2C) in FM-treated cows.

\section{DISCUSSION}

The success of the periparturient period has a significant impact on cow performance and can ultimately influence farm profitability. Dairy cows usually experience an energy deficit in early lactation because of an inability to consume enough energy to meet their energy requirements for maintenance and copious milk production. This negative EBAL during the peripartu- rient period is associated with increased metabolic and reproductive disorders (Drackley, 1999) and probably limits milk yield (Odens et al., 2007). In addition, immune function in periparturient cows is reduced and they become more susceptible to infection (Mallard et al., 1998).

The uterine tissue trauma and subsequent inflammation and potential fever associated with parturition maybe one possible reason for the inadequate postcalving appetite. To evaluate this, we administered FM immediately after parturition for the first 3 DIM in an attempt to reduce body temperature and inflammation, thereby increasing feed intake and improving bioenergetic variables. In contrast to our hypothesis, FM administration modestly increased rectal temperatures at 3 and 4 DIM (Table 2 and Figure 1) and caused more cows (4 vs. 9 ) to be classified as febrile.

The increased rectal temperature $\left(0.23^{\circ} \mathrm{C}\right)$ after $\mathrm{FM}$ treatment is generally not consistent with previous research on febrile animals (mastitis, metritis, Escheri-

Table 4. Effects of flunixin meglumine (FM) treatment in the first 3 DIM on milk composition of dairy cows in the first 5 wk of lactation

\begin{tabular}{|c|c|c|c|c|c|c|}
\hline \multirow[b]{2}{*}{ Milk variable, $\%$} & \multicolumn{2}{|c|}{ Treatment $^{1}$} & \multirow[b]{2}{*}{ SEM } & \multicolumn{3}{|c|}{$P$-value } \\
\hline & Control & FM & & $\mathrm{TRT}^{2}$ & DIM & $\mathrm{TRT} \times \mathrm{DIM}$ \\
\hline Fat & 3.88 & 3.94 & 0.16 & 0.79 & 0.06 & 0.96 \\
\hline Protein & 3.31 & 3.33 & 0.10 & 0.90 & $<0.01$ & 0.97 \\
\hline Lactose & 4.58 & 4.57 & 0.04 & 0.90 & $<0.01$ & 0.28 \\
\hline
\end{tabular}

${ }^{1}$ Treatments were $2.0 \mathrm{~mL}$ of saline $/ 45.5 \mathrm{~kg}$ of BW (control) or $2.2 \mathrm{mg}$ of FM/kg of BW for the first 3 DIM.

${ }^{2}$ Treatment. 

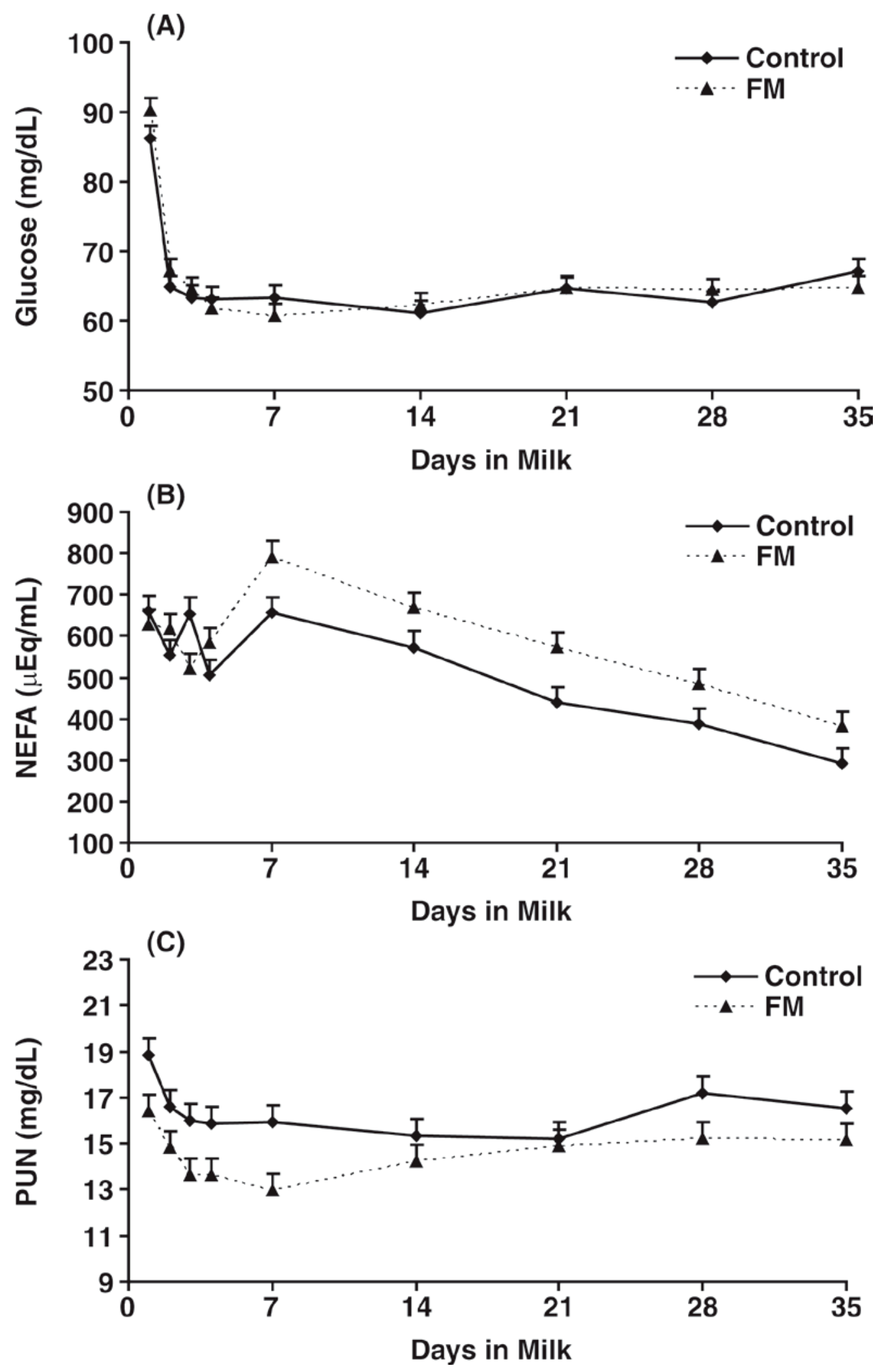

Figure 2. Effects of flunixin meglumine (FM) on plasma glucose (A), NEFA (B), and plasma urea nitrogen (PUN; C). Treatments were 2.0 $\mathrm{mL}$ of saline $/ 45.5 \mathrm{~kg}$ of BW (control) or $2.2 \mathrm{mg}$ of $\mathrm{FM} / \mathrm{kg}$ of BW for the first 3 DIM. Values represent least squares means $(\mathrm{n}=12$ or 14$)$ for the control and FM, respectively. $P$-values for treatment, DIM, and the treatment $\times$ DIM interaction were $0.86,<0.01$, and 0.98 , respectively, for glucose; $0.29,<0.01$, and 0.37 , respectively, for NEFA; and $0.08,<0.01$, and 0.53 , respectively, for PUN. 
chia coli, etc.; Anderson and Hunt, 1989; Amiridis et al., 2001; Wagner and Apley, 2004). However, FM treatment did not reduce rectal temperature in transition cows with retained placenta (Königsson et al., 2001), acute puerperal metritis (Drillich et al., 2007), or mastitis (Dascanio et al., 1995), or in heat-stressed lactating cows (Soto et al., 2003). Therefore, there are circumstances in which rectal temperature is resistant to an FM-induced change, and the mechanisms that contribute to this variability are poorly defined. During this study, 2 FM-treated cows retained their fetal membrane past $12 \mathrm{~h}$ postcalving, whereas none of the control cows did. In addition, these 2 cows were febrile on 2 to 7 and 3 to 6 DIM and had a colored vaginal discharge accompanied by vaginal odor, which might be a sign for puerperal metritis (Sheldon et al., 2006). These clinical signs cleared by 14 DIM.

We evaluated DMI on absolute values $(\mathrm{kg} / \mathrm{d})$ and as a percentage of $\mathrm{BW}$ (because of variation in $\mathrm{BW}$ between the 2 treatments before calving). Regardless of the evaluation method, cows destined for the FM treatment consumed less feed before calving and had less DMI immediately postpartum (1 to 7 DIM). Although not completely understood, the reduced DMI might have been caused by the small increase in FM-induced rectal temperature, because previous studies reported decreased DMI in febrile heifers (Steiger et al., 1999) and goats (Takeuchi et al., 1995). However, overall (1 to 5 wk of lactation) DMI as a percentage of BW was similar between treatments (Table 3), and this agrees with previous research by Königsson et al. (2001), who demonstrated that FM treatment (at a similar dose) of transition cows did not affect DMI in primiparous cows.

Milk production was analyzed both as an absolute value and as a percentage of BW because there was a positive correlation between BW and milk yield (Erb and Ashworth, 1961). Milk yield was reduced in FMtreated cows during the first 7 DIM (Table 2), but overall was not different throughout the study ( 1 to 5 wk of lactation; Table 3). These findings are consistent with a recent study (Drillich et al., 2007) in which no difference was found in milk yield in FM-treated cows compared with control cows. Although not well understood, it appears the reduced milk yield immediately postpartum was probably due to decreased nutrient intake because the temporal pattern of DMI closely parallels the temporal milk yield pattern (data not shown). Further evidence that suggests reduced DMI was responsible for the decreased milk yield in the current study is that the FM treatment did not reduce DMI, and thus milk yield, in transition cows (Königsson et al., 2001) or in mastitic cows (Dascanio et al., 1995; Wagner and Apley, 2004).
Flunixin meglumine-treated cows tended to have a reduced EBAL and improved feed efficiency during the first 7 DIM (Table 2), but both variables were similar between treatments during the first 5 wk of lactation (Table 3). To the best of our knowledge, this is the first trial to evaluate the effect of FM on EBAL and feed efficiency in transition dairy cows. Reduced DMI for FM-treated cows before calving and during the first 7 DIM probably caused the decreased EBAL. Furthermore, because of the reduced nutrient intake during the first week of lactation, FM-treated cows probably relied more on tissue-derived nutrients to support increasing milk yield, which would explain the increase in feed efficiency.

Flunixin meglumine-treated cows had similar plasma glucose and NEFA (Figures 2A and 2B), but tended to have lower PUN levels compared with control cows (Figure 2C). Previous research on neonatal calves exposed to E. coli and treated with FM (Semrad, 1993) demonstrated no effect of FM on glucose variables. To the best of our knowledge, no other study has evaluated the effects of FM on plasma NEFA and PUN during the transition period. Nonesterified fatty acids are a product of adipose mobilization, and increased NEFA in early lactation is thought to predispose cows to fatty liver and ketosis (Drackley, 1999). Plasma urea nitrogen can originate from a variety of sources, and because DMI was actually lower in FM-treated cows, the reduced PUN (Figure 2C) may have been due to less excess dietary AA needing hepatic deamination.

An alternative source of PUN is skeletal muscle breakdown, because cows in early lactation are in a negative protein balance, and muscle catabolism is the primary method of meeting the additional AA requirement during this period. Cytokine secretion during inflammation is partially responsible for immune-activated skeletal muscle proteolysis (Kotler, 2000). Baracos et al. (1983) indicated that increased IL-1 levels promoted protein catabolism via $\mathrm{PGE}_{2}$ accumulation in the muscle. Additionally, increased prostaglandin $\mathrm{E}_{2}$ in febrile rats enhanced muscle breakdown (Rodemann and Goldberg, 1981). Nonsteroidal antiinflammatory drugs (such as FM) reduce prostaglandin synthesis via cyclooxygenase inhibition (Morteau, 2000), and consequently reduce muscle proteolysis (Baracos et al., 1983; Goldberg et al., 1984). Thus, an additional reason (along with reduced protein intake) why FM-treated cows had reduced PUN may have been due to a decrease in skeletal muscle breakdown.

As stated earlier, the modest increase in rectal temperature in FM-treated cows during the current study was not expected, but might have resulted from vasodilatation inhibition and thus impaired heat dissipation. Surface or skin vasodilatation is a key mechanism cows 
use to dissipate heat (Neuwirth et al., 1979), and prostaglandins play a key role in vasodilatation (Neisius et al., 2002). Prostaglandins are produced from long-chain polyunsaturated fatty acids via cyclooxygenase- 1 and cyclooxygenase-2 (Dinarello, 1984), and reducing cyclooxygenase action reduces vasodilatation in humans (McCord et al., 2006). In addition, FM administration decreases prostaglandin synthesis via cyclooxygenase inhibition (Brander et al., 1991). Therefore, FM treatment may have impaired cutaneous vasodilatation, and this might have altered the efficiency of heat dissipation, ultimately leading to a minor rectal temperature increase in these nonfebrile cows.

\section{CONCLUSIONS}

The present study demonstrated that FM treatment to nonfebrile cows immediately postpartum for the first 3 DIM did not improve production variables in periparturient dairy cows. In fact, on an absolute basis, FM-treated cows consumed less feed and produced less milk. Identifying why FM-treated cows had a slightly increased rectal temperature during the first week of lactation is of interest.

\section{REFERENCES}

Abramson, S. 1991. Therapy with and mechanisms of nonsteroidal anti-inflammatory drugs. Curr. Opin. Rheumatol. 3:336-340.

Amiridis, G. S., L. Leontides, E. Tassos, P. Kostoulas, and G. C. Fthenakis. 2001. Flunixin meglumine accelerates uterine involution and shortens the calving-to-first-oestrus interval in cows with puerperal metritis. J. Vet. Pharmacol. Ther. 24:365-367.

Anderson, K. L., and E. Hunt. 1989. Anti-inflammatory therapy in acute endotoxin-induced bovine mastitis. Vet. Res. Commun. $13: 17-26$.

Baracos, V., H. P. Rodemann, C. A. Dinarello, and A. L. Goldberg. 1983. Stimulation of muscle protein degradation and prostaglandin $\mathrm{E}_{2}$ release by leukocytic pyrogen (interleukin-1). A mechanism for the increased degradation of muscle proteins during fever. $\mathrm{N}$. Engl. J. Med. 308:553-558.

Bondurant, R. H. 1999. Inflammation in the bovine female reproductive tract. J. Anim. Sci. 77(Suppl. 2):101-110.

Brander, G. C., D. M. Pugh, R. J. Bywater, and W. L. Jenkins. 1991. Veterinary Applied Pharmacology and Therapeutics. 5th ed. Bailliere Tindall, London, UK.

Dascanio, J. J., G. D. Mechor, Y. T. Grohn, D. G. Kenney, C. A. Booker, P. Thompson, C. L. Chiffelle, J. M. Musser, and L. D. Warnick. 1995. Effect of phenylbutazone and flunixin meglumine on acute toxic mastitis in dairy cows. Am. J. Vet. Res. 56:12131218.

Dinarello, C. A. 1984. Interleukin-1 and the pathogenesis of the acute phase response. N. Engl. J. Med. 311:1413-1418.

Drackley, J. K. 1999. Biology of dairy cows during the transition period: The final frontier? J. Dairy Sci. 82:2259-2273.

Drillich, M., D. Voigt, D. Forderung, and W. Heuwieser. 2007. Treatment of acute puerperal metritis with flunixin meglumine in addition to antibiotic treatment. J. Dairy Sci. 90:3758-3763.

Erb, R. E., and U. S. Ashworth. 1961. Relationships between age, body weight, and yield of dairy cows. J. Dairy Sci. 44:515-523.

Goldberg, A. L., V. Baracos, P. Rrodemann, L. Waxman, and C. Dinarello. 1984. Control of protein degradation in muscle by prostaglandins, $\mathrm{Ca}^{2+}$, and leukocytic pyrogen (interleukin-1). Fed. Proc. 43:1301-1306.

Hussain, A. M., and R. C. Daniel. 1991. Bovine endometritis: Current and future alternative therapy. Zentralbl. Veterinarmed. A $38: 641-651$

Königsson, K., H. Gustafsson, A. Gunnarsson, and H. Kindahl. 2001. Clinical and bacteriological aspects on the use of oxytetracycline and flunixin in primiparous cows with induced retained placenta and post-partal endometritis. Reprod. Domest. Anim. 36:247256.

Kotler, D. P. 2000. Cachexia. Ann. Intern. Med. 133:622-634.

Lewis, G. S. 1997. Uterine health and disorders. J. Dairy Sci. 80:984994.

Mallard, B. A., J. C. Dekkers, M. J. Ireland, K. E. Leslie, S. Sharif, C. L. Vankampen, L. Wagter, and B. N. Wilkie. 1998. Alteration in immune responsiveness during the peripartum period and its ramification on dairy cow and calf health. J. Dairy Sci. 81:585595.

McCord, G. R., J. L. Cracowski, and C. T. Minson. 2006. Prostanoids contribute to cutaneous active vasodilation in humans. Am. J. Physiol. Regul. Integr. Comp. Physiol. 291:R596-R602.

Morteau, O. 2000. Prostaglandins and inflammation: The cyclooxygenase controversy. Arch. Immunol. Ther. Exp. (Warsz.) 48:473-480.

NRC. 2001. Nutrient Requirements of Dairy Cattle. 7th rev. ed. Natl. Acad. Press, Washington DC.

Neisius, U., R. Olsson, R. Rukwied, G. Lischetzki, and M. Schmelz. 2002. Prostaglandin $\mathrm{E}_{2}$ induces vasodilation and pruritus, but no protein extravasation in atopic dermatitis and controls. J. Am. Acad. Dermatol. 47:28-32.

Neuwirth, J. G., J. K. Norton, C. A. Rawlings, F. N. Thompson, and G. O. Ware. 1979. Physiologic responses of dairy calves to environmental heat stress. Int. J. Biometeorol. 23:243-254.

Odens, L. J., R. Burgos, M. Innocente, M. J. VanBaale, and L. H. Baumgard. 2007. Effects of varying doses of supplemental CLA on production parameters and energetic variables during the transition period. J. Dairy Sci. 90:293-305.

Rodemann, H. P., and A. L. Goldberg. 1981. Arachidonic acid, prostaglandin $\mathrm{E}_{2}$ and $\mathrm{F}_{2}$ alpha influence rates of protein turnover in skeletal and cardiac muscle. J. Biol. Chem. 257:1632-1638.

SAS Institute. 2005. SAS/STAT Users Guide. Release 9.3. SAS Inst. Inc., Cary, NC.

Semrad, S. D. 1993. Comparison of flunixin, prednisolone, dimethyl sulfoxide, and a lazaroid (U74389F) for treating endotoxemic neonatal calves. Am. J. Vet. Res. 54:1517-1522.

Sheldon, I. M., G. S. Lewis, S. LeBlanc, and R. O. Gilbert. 2006. Defining postpartum uterine disease in cattle. Theriogenology 65:1516-1530

Sheldon, I. M., A. N. Rycroft, and C. Zhou. 2004. Association between postpartum pyrexia and uterine bacterial infection in dairy cattle. Vet. Rec. 154:289-293.

Soto, P., R. P. Natzke, and P. J. Hansen. 2003. Role of prostaglandins in the development of hyperthermia in heat-stressed, lactating Holstein cows. J. Vet. Pharmacol. Ther. 26:435-437.

Steiger, M., M. Senn, G. Altreuther, D. Werling, F. Sutter, M. Kreuzer, and W. Langhans. 1999. Effect of a prolonged low-dose lipopolysaccharide infusion on feed intake and metabolism in heifers. J. Anim. Sci. 77:2523-2532.

Takeuchi, Y., T. Kikusui, and Y. Mori. 1995. Changes in the behavioral parameters following the lipopolysaccharide administration in goats. J. Vet. Med. Sci. 57:1041-1044.

Tizard, I. R. 1996. Hypersensitivity. Pages 343-401 in Veterinary Immunology: An Introduction. 5th ed. W. B. Saunders Co., Philadelphia, PA.

Wagner, S. A., and M. D. Apley. 2004. Effects of two anti-inflammatory drugs on physiologic variables and milk production in cows with endotoxin-induced mastitis. Am. J. Vet. Res. 65:64-68.

Wildman, E. E., G. M. Jones, P. E. Wagner, R. L. Boman, H. F. Troutt Jr., and T. N. Lesch. 1982. A dairy cow body condition scoring system and its relationship to selected production characteristics. J. Dairy Sci. 65:495-501. 